\title{
CADM1 wt Allele
}

National Cancer Institute

\section{Source}

National Cancer Institute. CADM1 wt Allele. NCI Thesaurus. Code C106270.

Human CADM1 wild-type allele is located in the vicinity of $11 \mathrm{q} 23.2$ and is approximately $336 \mathrm{~kb}$ in length. This allele, which encodes cell adhesion molecule 1 protein, is involved in the modulation of cell-cell adhesion. 